\title{
A contribution to the process of designing for learning in Massive Open Online Courses (MOOCs)
}

\author{
Aracele G. O. Fassbinder ${ }^{1,2}$, Ellen Francine Barbosa (advisor) ${ }^{2}$ \\ ${ }^{1}$ Federal Institute of Education, Science and Technology of South of Minas Gerais \\ (IFSULDEMINAS - Campus Muzambinho) - Muzambinho, Minas Gerais, Brazil. \\ ${ }^{2}$ Institute of Mathematics and Computer Sciences, University of São Paulo \\ (ICMC-USP) - São Carlos, São Paulo, Brazil. \\ aracele.garcia@muz.ifsuldeminas.edu.br, francinedicmc.usp.br
}

\begin{abstract}
The design and development of MOOCs require the use of appropriate mechanisms and systematic procedures to ensure the standardization and the productivity of all aspects involved in the MOOC development process, as well as to meet the desired quality of the resulting materials. In this perspective, the results introduced in this work contribute with theoretical improvements and practical advances in the development of MOOCs and to enhance the construction of software platforms and providers. In addition, new methods and strategies to support lifelong learning in Software Engineering through open and online courses are also investigated.
\end{abstract}

\section{Introduction}

Massive Open Online Courses (MOOCs) are an instance of the open and online education movement that over the last years have promoted a lot of discussion among the educational and technological communities [Conole 2014; Margaryan, Bianco and Littlejohn 2015]. In short, a MOOC is an online course with the option of free and open registration, an open curriculum, and open-ended outcomes [Mcauley et al. 2010; Zhu, Sari and Lee 2018]. It can serve as a driver of diversity in education; enhance students' learning by encouraging and engaging them for lifelong learning; create opportunities of transition to formal higher education or lifelong learning activities; promote a re-conceptualization of higher education through the use of online study; enhance teachers' skills from developing Open Educational Resources (OERs) and adopting learner-centered pedagogical approaches and active learning strategies.

Besides the great potential of MOOCs for technology enhanced learning, there still are challenges related to their effectiveness, and widespread production and adoption. One challenge faced by MOOC teams (including instructors and learning designers) is that welldefined and validated strategies to support practitioners in the MOOC development are still under investigated, despite research efforts from the Learning Design [Koper and Tattersall 2005; Dalziel et al. 2016], Computer Science, and Educational communities. As a result, practitioners and learners have experienced issues associated to teaching and learning in a massive, open and online environment. For example, the design of innovative and groundbreaking MOOCs has been a difficult task for practitioners, especially novices, since there is no well-defined standard about the desirable design characteristics of MOOC courses [Schophuizen et al. 2018]. Another challenge is that most of the existing MOOCs are still pedagogically based on traditional classroom formats, such as teacher-centered approaches and content-based learning, which are less effective as a means of learning in the MOOC context [Fassbinder, Delamaro and Barbosa 2014; Zhu, Sari and Lee 2018]. 
Similarly to the software development, the design of MOOCs requires the use of appropriate mechanisms and systematic procedures to ensure the standardization and the productivity of all aspects involved in the MOOC development process, as well as to meet the desired quality of the resulting materials. Thus, considering the context and challenges previously described, this work focuses on the development and validation of a learning design strategy for MOOCs, which is grounded on the perspective of Software Engineering principles so that it can contribute to support MOOC teams when designing for learning in this context. Such strategy, called LDF4MOOCs (Learning Design Framework for MOOCs), consists of: (i) a MOOC Life Cycle process, which describes fundamental steps to plan, offer and evaluate a MOOC; (ii) an Educational Design Pattern Language for MOOCs, which is based on problems and recurring solutions to solve the main activities described in the life cycle; and (iii) related supporting resources. LDF4MOOCs is also pedagogically informed by Flipped Learning ideas [Bergmann and Sams 2014].

In this paper, we focused on the essential parts of the work. More details can be found in the Ph.D. thesis [Fassbinder 2018]. The remainder of this paper is organized as follows. In Section 2, we summarize the related work. In Section 3, we present the research strategy used to guide this study. In Section 4, we summarize the rationale underpinning our proposal, followed by an overview of the main characteristics and elements of LDF4MOOCs, and how they can be useful for the development of MOOCs. In Section 5, we present the main strategies used to validate LDF4MOOCs and its elements. Finally, our conclusions and perspectives for future work are presented in Section 6.

\section{Related Work}

The rapid growing interest of institutions and educators in designing and delivering MOOCs, either using popular providers, such as Coursera ${ }^{1}$, edX $\mathrm{X}^{2}$, and Future Learn ${ }^{3}$, or adapting open platforms to their own infrastructure, such as Google Course Builder ${ }^{4}$, open edX ${ }^{5}$, and the Brazilian instance named $\operatorname{Tim~Tec}^{6}$, has revealed gaps that need to be further investigated. As previously highlighted, some of the main open issues are related to the lack of specific learning design approaches that support practitioners when developing MOOCs. There is also a need for incorporating more creative and empowering categories of pedagogical strategies for open online learning.

There are different mechanisms to capture and encapsulate knowledge related to learning design [Koper and Tattersall 2005]. For instance, theories consisting in a set of design principles; identification of best practices in teaching and learning; and the formalization of knowledge and best practices through patterns and pattern languages [Pressman 2009; Alexander, Ishikawa and Silverstein 1977]. To advance the understanding of how instructors are designing learning experiences, and also to find ways to improve the current practice of MOOCs development, we performed a systematic review [Fassbinder, Delamaro and Barbosa 2014]. Table 1 summarizes the main approaches specifically created to support practitioners when designing for learning in the MOOC context.

\footnotetext{
${ }^{1}$ https://www.coursera.org/

${ }^{2}$ https://www.edx.org

${ }^{3} \mathrm{https}: / /$ www.futurelearn.com/

${ }^{4}$ https://edu.google.com/openonline/

${ }^{5} \mathrm{https}$ //open.edx.org/

${ }^{6} \mathrm{https}: / /$ timtec.com.br/pt/funcionalidades/
} 
VIII Congresso Brasileiro de Informática na Educação (CBIE 2019)

Anais dos Workshops do VIII Congresso Brasileiro de Informática na Educação (WCBIE 2019)

Table 1. Specific approaches to develop MOOCs, and their validation strategies.

\begin{tabular}{c|l|l}
\hline Approaches & \multicolumn{1}{|c|}{ Results } & \multicolumn{1}{c}{ Construction and validation strategies } \\
\hline [Lee et al. 2016] & $\begin{array}{l}\text { A MOOC Design Model in the form } \\
\text { of a figure with course development } \\
\text { procedures and activities. }\end{array}$ & $\begin{array}{l}\text { Internal Validation (instructional designers, MOOC experts); } \\
\text { External Validation (field test: interviews and questionnaire } \\
\text { of teachers and learners). }\end{array}$ \\
\hline $\begin{array}{c}\text { [Warburton and Mor } \\
\text { 2015] }\end{array}$ & $\begin{array}{l}\text { A set of 25 patterns for the structured } \\
\text { design of MOOCs. }\end{array}$ & $\begin{array}{l}\text { Design scenario workshop and Pattern Languages of } \\
\text { Programs Conference (PLoP). }\end{array}$ \\
\hline $\begin{array}{c}\text { [Liyanagunawardena, } \\
\text { Kennedy and Cuffe } \\
2015]\end{array}$ & $\begin{array}{l}\text { Three different design patterns to } \\
\text { promote peer interaction in } \\
\text { discussion forums in MOOCs. }\end{array}$ & $\begin{array}{l}\text { A series of workshops, which aimed to identify MOOC } \\
\text { design principles from the participants' experiences. }\end{array}$ \\
\hline [Alario-Hoyos et al. & $\begin{array}{l}\text { A conceptual framework in the form } \\
\text { of a canvas, i.e., a visual } \\
\text { representation of blocks or issues. }\end{array}$ & $\begin{array}{l}\text { A case study consisting of six educators with technological } \\
\text { background that participated in a workshop and used the } \\
\text { proposed strategy to design a MOOC. }\end{array}$ \\
\hline [Brouns et al. 2014] & $\begin{array}{l}\text { A networked learning framework for } \\
\text { MOOC design. }\end{array}$ & $\begin{array}{l}\text { The quality and validity of the pedagogical framework were } \\
\text { not considered by the authors (future work). }\end{array}$ \\
\hline
\end{tabular}

We noticed that few approaches aimed to specifically improve the learning design of MOOCs. Besides, they neither provide comprehensive information on how MOOCs should be developed, nor explicitly describe their development/evaluation process and their benefits on MOOCs design. Traditional approaches have also been applied for the MOOCs context; for example, some strategies are based on the ADDIE model [Branch 2010], but few specific MOOC characteristics are considered during the design. Based on lessons learned from experiments, case studies and field evaluation, some authors have proposed design principles and essential characteristics that should be considered by instructors when designing a MOOC. However, they only provide general guidance for MOOCs design.

In addition to reviewing the learning design strategies currently in use by MOOC teams, we also carried out a survey in which MOOC instructors were asked about their experiences designing MOOCs. Data collection was performed from December 2015 to July 2016. At the end, 91 questionnaire responses were collected; participation was voluntary, and no incentives or rewards were offered. The majority was from Brazil $(n=24)$, USA $(n=15)$, and France $(n=8)$. Regarding the preferred learning design strategies to design MOOCs, the majority (44\%) develops MOOCs using their own experience (i.e., no defined approach is used to guide the MOOC development). Other strategies used are based on guidelines produced by MOOC providers $(24 \%)$ or institutions/universities $(12 \%)$. Another gap identified is regarding the preferred pedagogical approaches used to design for learning in MOOCs. The majority of the respondents $(58 \%)$ have adopted content-based approaches (e.g., based on video-lectures, forums, formative quizzes, and automatic assessments).

In short, from the systematic review and the survey results, we noticed that the issues related to the lack of well-defined and validated strategies to support practitioners in the MOOC development are still challenges to be overcome worldwide. In this context, a Learning Design Framework for MOOCs, named LDF4MOOCs, was proposed and evaluated. Our framework differs from other strategies to design for learning in MOOCs in several aspects: (i) it focuses on the entire MOOC design process; (ii) it is pedagogically informed by Flipped Learning ideas and fundamentals, which act as an effective intervention to support learning in MOOCs, helping learners to take the active role in their own acquisition process of skills and knowledge construction; (iii) it is ground on Software Engineering mechanisms and systematic procedures to ensure the standardization and the productivity of all the aspects involved in the MOOC development process; and (iv) the framework and its main elements were validated by an iterative process that contemplates different methods to investigate the effects of using LDF4MOOCs under different stakeholders' viewpoint. 
VIII Congresso Brasileiro de Informática na Educação (CBIE 2019)

Anais dos Workshops do VIII Congresso Brasileiro de Informática na Educação (WCBIE 2019)

\section{Research Design}

Educational Design Research (EDR) was the main strategy used to achieve the purpose of this work. EDR is an interactive and iterative process composed of the following general phases: context identification and problem analysis (analysis and exploration); development and refinement of interventions (design and construction); continuous evaluation, reflection and learning through all the phases (evaluation); final theorization through lessons learned, design principles, artifacts, among others (implementation and spread). Anderson and Shattuck (2012), and Mckenney and Reeves (2019) define this type of design research as the systematic analysis, design and evaluation of educational interventions with the dual aim of generating research-based solutions for complex problems in educational practice, and advancing our knowledge about the characteristics of these interventions and the processes of designing and developing them.

\section{A Learning Design Framework for MOOCs}

In this section we discuss the establishment of a learning design framework that can be used by practitioners and technologists when studying, designing or developing MOOCs as well as mechanisms related to them (e.g., virtual learning environments, learning design tools).

A learning design framework aims to help teachers/designers make design decisions that are pedagogically effective and make appropriate use of digital technologies [Conole 2014]. According to Bannan (2013), there are thousands of decisions that need to be made in a design context and such type of framework is a step towards the articulation and documentation of common phases and complementary stages based on practice and research processes that promote a more conscious design.

\subsection{Overview}

The ideas and solutions embodied in the proposed Learning Design Framework for MOOCs, also called LDF4MOOCs, are mainly grounded on practices of Software Engineering, i.e., systematic and well-defined methods, techniques, and processes. Such practices are embedded in the development of MOOCs aiming at improving quality as well as facilitating reuse and adaptation. The proposed framework consists of: (i) a MOOC Life Cycle process, which describes fundamental steps to plan, offer, and evaluate a MOOC; (ii) an Educational Design Pattern Language for MOOCs, that is based on problems and recurring solutions to solve the main activities described in the MOOCs Life Cycle; and (iii) related supporting resources (artifacts and digital tools). The elements are related, and their use together make the framework stronger. However, there is no usage dependency between them. It means they can be used independently, if the users so desire.

The target audience of LDF4MOOCs is teachers, learning designers, researchers, technologists, among other people interested in the MOOC development process. However, our focus is small MOOC teams and even single teachers with limited financial, technological, and human resources, in order to empower them and enhance their work. We also had the concern of drawing the framework having novice MOOC practitioners in mind, which is very important in the incipient, but expanding MOOC context. Regarding the main roles related to the proposed framework, the idea is to create means to empower and promote a re-thinking to have: (i) educators as learning designers; (ii) students as active learners; and (iii) virtual platforms as creative spaces to support self and collaborative learning. Regarding its applicability, LDF4MOOCs is written to cover a general MOOC project, about any educational topic. Regarding the pedagogical aspects, LDF4MOOCs draws upon Flipped Learning [Bergmann and Sams 2014] and active methodologies of teaching and learning as 
VIII Congresso Brasileiro de Informática na Educação (CBIE 2019)

Anais dos Workshops do VIII Congresso Brasileiro de Informática na Educação (WCBIE 2019)

pedagogical strategy. This means that MOOCs created through it will be instigated to use active learning activities, strategies to support self-regulated learning, competency-based learning, among other characteristics. Next, we detail the framework elements, focusing on their main characteristics.

\subsection{MOOC Life Cycle Process}

Aiming to move towards the exploration of a common structure to support educators, learning designers, technologists and institutions involved with the MOOC development and maintenance, a MOOC Life Cycle was proposed. Its current version is shown in Figure 1; its refinement and evolution process can be found in [Fassbinder et al. 2016; Fassbinder, Barbosa and Magoulas 2017a, 2017b]. The conceptual and visual model represents the main steps from an initial idea or need to the delivery of a MOOC and its evaluation phase. It provides a comprehensive structure for systematically create MOOCs.

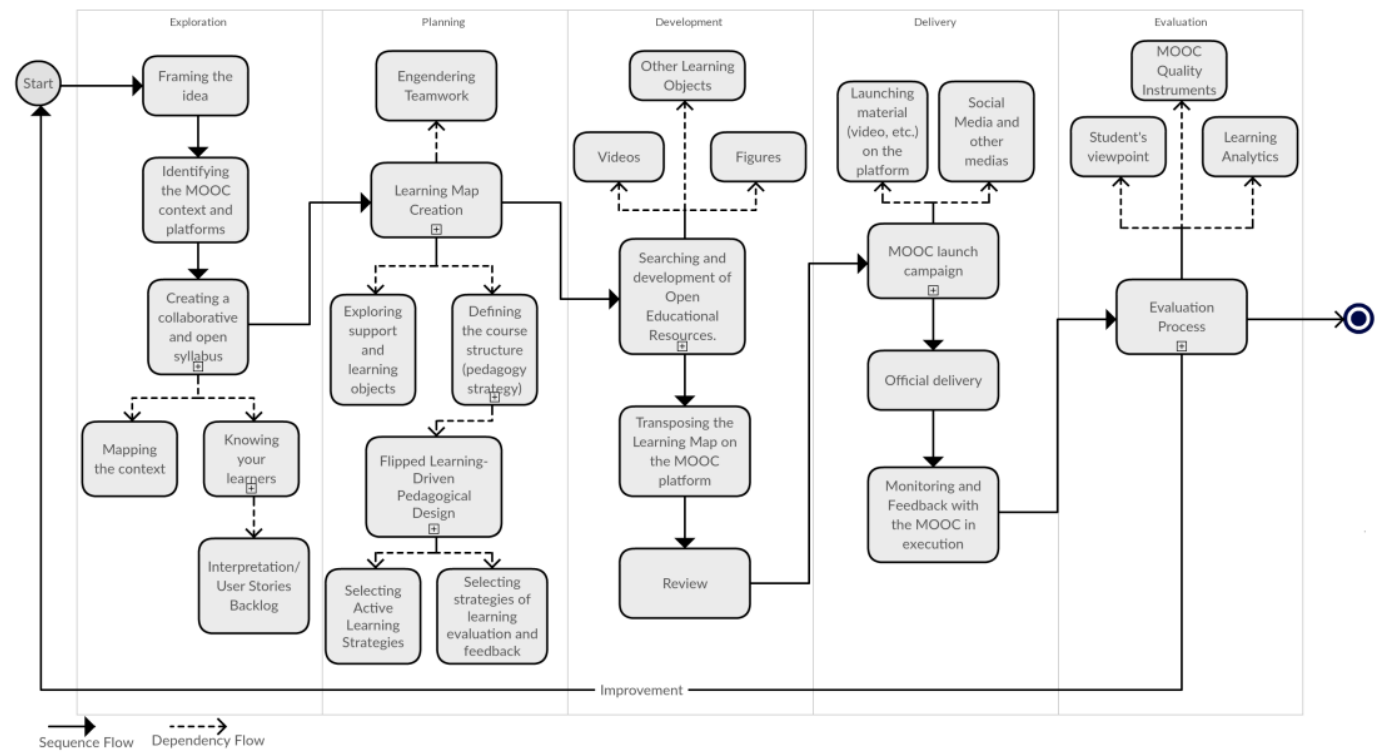

Figure 1. A Life Cycle Process for MOOCs.

The core element of LDF4MOOCs framework is a MOOC design approach based on educational design patterns. Following we describe a Pattern Language (PL) to support design for learning in MOOCs; the subsection is grounded on the main studies we already published about the language [Fassbinder, Barbosa and Magoulas 2017a, 2017b].

\subsection{An Educational Design Pattern Language for MOOCs}

The design of innovative and disruptive MOOCs has been a difficult task for practitioners, especially novices, since well-known methodological design strategies and desirable characteristics for MOOC projects are still underexplored [Hew and Cheung 2014; Sergis, Sampson and Pelliccione 2016]. Design patterns and pattern languages attempt to mitigate this situation by providing instructors and MOOC teams with empirical theory-driven practices that could help them to enhance the course quality.

Our approach for the PL development is a mixture of procedures defined by [Braga, Ré and Masiero 2007; Iba, Sakamoto and Miyake 2011; Meszaros and Doble 1997] and encompasses seven main phases, as summarized in Figure 2. While the MOOC Life Cycle provides a high-level overview of the phases and activities regarded to the MOOC development (i.e., "what-to-do" items), the proposed patterns-based approach establishes a way of "how-to-do" and congregates practical aspects to enhance the design for learning. The 
VIII Congresso Brasileiro de Informática na Educação (CBIE 2019)

Anais dos Workshops do VIII Congresso Brasileiro de Informática na Educação (WCBIE 2019)

'blueprint' resulting from the 'Domain Model Creation' phase (i.e. the MOOC Life Cycle) helped us to identify the acts of experts and then understand the knack of the acts. According to Iba, Sakamoto and Miyake (2011), the extracted knacks are potential ideas for patterns, also named candidate patterns or proto-patterns. The corresponding problem to the solution may be related to the design activities presented in the domain model. The first patterns core elements were described as name, context, problem, and solution. The candidate patterns were also grouped into "families of patterns" that shared design goals.

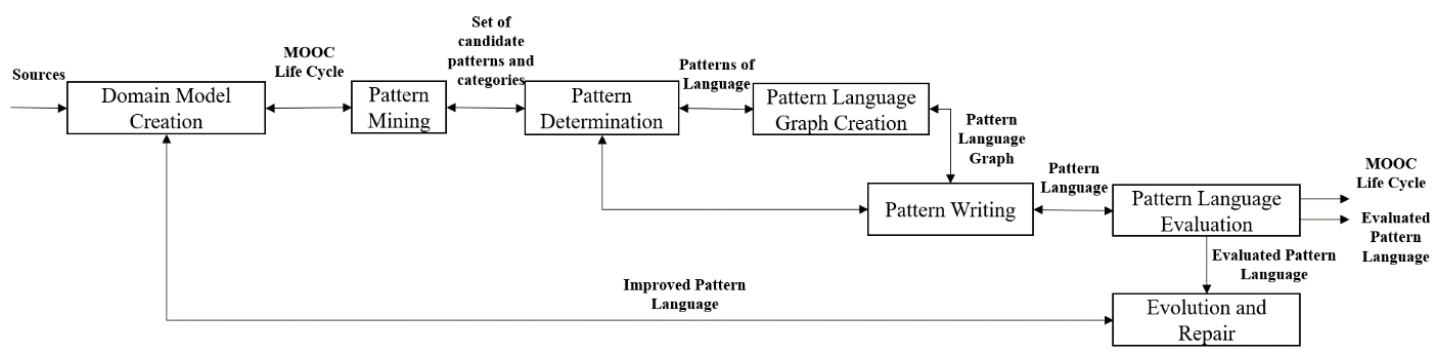

Figure 2. The PL development process.

Figure 3 presents the PL related graph. The 49 patterns are grouped into eight categories representing practitioners' experiences. In addition to encourage sharing knowledge, the pattern language also gives each person who uses it the power to create a variety of new learning designs.

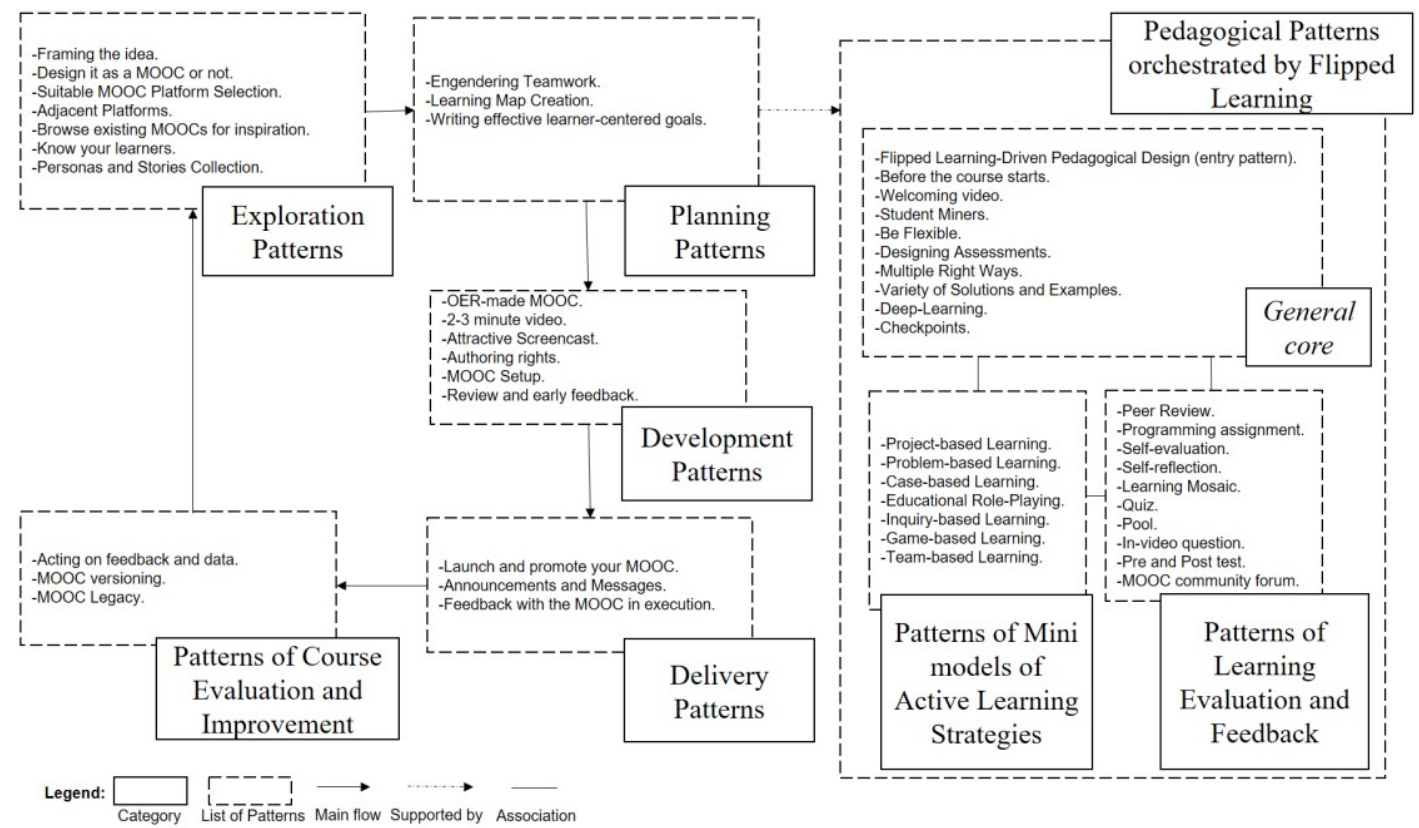

Figure 3. Educational Design Pattern Language graph.

In our $\mathrm{PhD}$ thesis, all the corresponding patterns are briefly presented in the form of patlets (problem-solution pair), and two patterns, called LEARNING MAP CREATION and FLiPPED LEARNING-DRIVEN PEDAGogical DEsign, are detailed. All the patterns are also available online at caed.icmc.usp.br/mooc. In this paper, due to space limitations, few patlets are described, in Tables 2 and 3. It is important to notice that patterns' names are described using the COPPERPLATE GOTHIC LIGHT font, while categories of patterns use the same font, but are UNDERLINED. 
VIII Congresso Brasileiro de Informática na Educação (CBIE 2019)

Anais dos Workshops do VIII Congresso Brasileiro de Informática na Educação (WCBIE 2019)

Table 2. An example of pattern (patlet) to support the Exploration Phase.

\begin{tabular}{c|l}
\hline Pattern Name & \multicolumn{1}{c}{ Brief Description (problem-solution pair) } \\
\hline DESIGN IT AS A & $\begin{array}{l}\text { You need to understand the desirable characteristics of a MOOC before creating one, but you do not know } \\
\text { how to start. Besides, there is no well-known definition for MOOCs and several authors have proposed } \\
\text { design guidelines and principles for their development. Finding and reading all available content can be hard } \\
\text { work. Therefore, a synthesis of characteristics and aspects, which must be considered in MOOCs, is listed } \\
\text { in an instrument named "Instrument to Support the Evaluation of Learning Maps in the MOOC Context } \\
\text { (Appendix C in the thesis)". The instrument is available online and can be used as a guide for practitioners } \\
\text { mainly at the beginning of the MOOC development. }\end{array}$ \\
\hline
\end{tabular}

As a top-level pedagogical strategy, we consider the use of Flipped Learning ideas adapted to the massive, open and online context. The point is understanding Flipped Learning as a framework that is based on several theories which help the MOOC team to scrutinize the use of diverse sets of characteristics required for MOOCs (DESIGN IT AS A MOOC OR NOT) and PATTERNS OF MINI MODELS OF ACTIVE LEARNING STRATEgIES. Table 3 summarizes some patterns based on Flipped Learning ideas.

Table 3. Examples of patterns, in the form of patlets, that summarizes models of Active Learning Strategies adapted to the MOOC context.

\begin{tabular}{|c|c|}
\hline Pattern Name & Brief Description (problem-solution pair) \\
\hline PROJECT-BASED LEARNING & \multirow{6}{*}{$\begin{array}{l}\text { You want to develop an authentic, flexible, and active MOOC using active learning } \\
\text { strategies. You may know how to apply those strategies in a face-to-face context or } \\
\text { even a formal virtual course, but you are unaware of any methods for adapting and } \\
\text { applying these strategies in a massive and virtual context. Therefore, considering that } \\
\text { such strategies are not new and there are existing patterns related to them, mainly from } \\
\text { face-to-face environments, the presented adapted solutions describe steps to apply } \\
\text { each of them considering their specificities. The full version of these patterns } \\
\text { describes steps to apply the related active learning strategy but adapted to the MOOC } \\
\text { context. }\end{array}$} \\
\hline PROBLEM-BASED LEARNING & \\
\hline CASE-BASED LEARNING & \\
\hline EDUCATIONAL ROLE-PLAYING & \\
\hline INQUIRY-BASED LEARNING & \\
\hline TEAM-BASED LEARNING & \\
\hline
\end{tabular}

\subsection{Supporting resources}

The need for artifacts and tools to support specific activities in the development of MOOCs also emerged during the refinement of the framework: (i) a template of Learning Map; (ii) an Instrument to Support the Evaluation of Learning Maps in the MOOC Context (Appendix C in the thesis); and (iii) the framework's website ${ }^{7}$. Some resources were adapted for the MOOC context, such as the Learning Map template, but others were created specifically to meet the MOOC development needs and are now an essential part of the framework. Digital tools were created to support practitioners in the main activities of the MOOCs development and also correlated practices, such as patterns management. Such tools are part of studies derived from this work and their development was supervised by the author of this thesis [Silva, Barbosa and Fassbinder 2017].

\section{Evaluation}

LDF4MOOCs and its elements were evaluated through an experimental study, five case studies, and two expert reviews as internal evaluation methods. Additionally, a field evaluation with educators using the framework as a guide to design their MOOCs was considered as an external evaluation method.

In the experimental study, Wilcoxon signed rank tests were employed to illustrate whether there were any differences between using ad hoc and LDF4MOOCs approaches in terms of adherence of the produced Learning Maps to the desirable characteristics for MOOCs. Considering all dimensions together, i.e., the global adherence of the produced

\footnotetext{
${ }^{7}$ http://caed.icmc.usp.br/mooc
} 
Learning Maps to the desirable characteristics for MOOCs specified in the rubric used by the participants, there was a significant difference between the maps built on an ad hoc basis and those guided by the LDF4MOOCs. LDF4MOOCs-based maps had a higher average score for adherence to the desirable characteristics for MOOCs than those developed by using an ad hoc basis.

The case studies, in turn, provided a deeper understanding about the MOOCs development. They acted as formative evaluation of LDF4MOOCs and increased our understanding on the use of the framework in real contexts. Five courses were created: three of them related to Software Engineering Education (SEE), as presented in Table 4; one metaMOOC; and one experimental and meta-learning design MOOC. Case studies related to SEE were also an opportunity to explore teaching and learning in software engineering-based MOOCs and how they could be better pedagogically designed. The learning design decisions made for each case study and the data collected from platforms and surveys suggest that using LDF4MOOCs can have a positive impact on the design for learning in MOOCs.

Table 4. List of SEE-based MOOCs developed during the work.

\begin{tabular}{c|c|c}
\hline Agile Software Development & $\begin{array}{l}\text { Web Development with Bootstrap, } \\
\text { CodeIgniter, and Agile Practices }\end{array}$ & Introduction to Software Testing \\
\hline $\begin{array}{l}\text { A course about Agile software } \\
\text { development using Project and } \\
\text { Problem-based Learning, and a learning } \\
\text { community on Facebook. }\end{array}$ & $\begin{array}{l}\text { A practice-driven introductory course } \\
\text { that used the Project-Based Learning } \\
\text { approach as the main strategy to support } \\
\text { the development of web development } \\
\text { skills and agile practices. }\end{array}$ & $\begin{array}{l}\text { A specific introductory course in the } \\
\text { Case-Based Learning as the main } \\
\text { pedagogical strategy. }\end{array}$ \\
\hline $\begin{array}{c}\text { Provider: Tim Tec }{ }^{8} \\
\text { Partner: IFSULDEMINAS }\end{array}$ & $\begin{array}{c}\text { Provider: MiríadaX } \\
\text { Partner: IFSULDEMINAS } \\
\text { Partner: USP }\end{array}$ \\
\hline
\end{tabular}

Beyond the experimental study and the case studies, two types of expert reviews were performed as internal validation methods. One with six patterns specialists from the PLoP Conference ${ }^{11}$, who focused on the patterns content and the pattern language structure, and one with 11 learning designers who explored pedagogical aspects of the framework by considering learnability, effectiveness, and user satisfaction. The items of the framework were modified and supplemented by considering the experience and practical perspectives of the patterns experts and learning designers. In the experts review with learning designers, the Fleiss' Kappa and the Kendall tests of concordance were shown to be useful tools for verifying the consensus among the participating experts. Both reviews showed preliminary evidences that the framework can be effectively applied to the design of MOOCs.

Lastly, we performed a field evaluation used as an external validation method to confirm the feasibility of LDF4MOOCs. The field evaluation, with 15 participants, provided more meaningful information about the use of the framework in natural settings than in a laboratory setting.

\section{Conclusions, thesis impact and future works}

The obtained results indicated that LDF4MOOCs has a positive and significant impact on the design for learning in MOOCs, suggesting that our innovative strategy advances the state-ofthe-art towards MOOC development. Such advance is important since the creation and adoption of MOOCs can bring many benefits and impact on education.

\footnotetext{
${ }^{8}$ https://mooc.ifsuldeminas.edu.br/course/desenvolvimento-agil-de-software/intro/

${ }^{9} \mathrm{https}: / /$ miriadax.net/web/desenvolvimento-web-com-bootstrap-codeigniter-e-praticas-ageis

${ }^{10} \mathrm{https}$ ://www.coursera.org/learn/intro-teste-de-software

${ }^{11} \mathrm{https}: / / w w w . h i l l s i d e . n e t / p l o p / 2017 /$
} 
VIII Congresso Brasileiro de Informática na Educação (CBIE 2019)

Anais dos Workshops do VIII Congresso Brasileiro de Informática na Educação (WCBIE 2019)

Other contributions include: (i) characterization of the state-of-the-art on MOOCs; (ii) characterization of the state-of-the-art on existing learning design strategies for MOOCs; (iii) proposition of desirable characteristics for MOOC Learning Maps; (iv) development of Open Educational Resources for Software Engineering Education [Fassbinder et al. 2017c]; (v) artifacts and tools to support learning design with LDF4MOOCs. The main publications resulting from our work are summarized in Table 5.

Table 5. Main publications.

\begin{tabular}{|c|c|}
\hline Main subject & Reference \\
\hline $\begin{array}{l}\text { Development of learning } \\
\text { projects for MOOCs }\end{array}$ & $\begin{array}{l}\text { Valente, J. A. V.; Freire, F. M. P. and Arantes, F. L. (2018). Tecnologia e Educação: passado, presente } \\
\text { e o que está por vir. Fassbinder, A. G. O. and Barbosa, E. F. Capítulo 10, Construção de projetos de } \\
\text { aprendizagem para MOOCs Campinas: Unicamp/NIED. }\end{array}$ \\
\hline $\begin{array}{l}\text { LDF4MOOCs and Web } \\
\text { Development Education- } \\
\text { based MOOCs }\end{array}$ & $\begin{array}{l}\text { Fassbinder, A. G. O.; Fassbinder, M. and Barbosa, E. F. (2018) Massive Open Online Courses on } \\
\text { Web Development Education: A Case Study. In: } 48^{\text {th }} \text { Frontiers in Education (FIE) Conference. San } \\
\text { Jose, California, USA, } 2018 \text {. }\end{array}$ \\
\hline $\begin{array}{l}\text { Educational Design } \\
\text { Pattern Language }\end{array}$ & $\begin{array}{l}\text { Fassbinder, A. G. O.; Magoulas, G. and Barbosa, E. F. (2017) Developing an Educational Design } \\
\text { Pattern Language for MOOCs. In: XXVIII Simpósio Brasileiro de Informática na Educação } \\
\text { (SBIE). Pernambuco, Brasil, 2017. }\end{array}$ \\
\hline $\begin{array}{l}\text { Self-regulated learning } \\
\quad \text { in MOOCs }\end{array}$ & $\begin{array}{l}\text { Fassbinder, A. G. O. and Barbosa, E. F. (2017) Estudo e Aplicação da técnica Learning Mosaic no } \\
\text { apoio à autorregulação da aprendizagem em Cursos Abertos Online e Massivos (MOOCs). In: } \\
\text { XXIII Workshop de Informática na Escola (WIE), Pernambuco, Brasil. }\end{array}$ \\
\hline $\begin{array}{l}\text { Educational Design } \\
\text { Pattern Language }\end{array}$ & $\begin{array}{l}\text { Fassbinder, A. G. O.; Magoulas, G. and Barbosa, E. F. (2017) Towards an Educational Design } \\
\text { Pattern Language for Massive Open Online Courses (MOOCs). In: 24th Conference on Pattern } \\
\text { Languages of Programs (PLoP). Vancouver, Canada, } 2017 .\end{array}$ \\
\hline $\begin{array}{l}\text { MOOCs in Software } \\
\text { Engineering Education }\end{array}$ & $\begin{array}{l}\text { Fassbinder, A. G. O.; Fassbinder, M; Barbosa, E. F. and Magoulas, G. (2017) Massive Open Online } \\
\text { Courses in Software Engineering Education. In: 47 } \\
\text { Conference. Indianapolis, USA, 2017. }\end{array}$ \\
\hline Lifelong Learning & $\begin{array}{l}\text { Fassbinder, A. G. O. et al. (2017) Repensando o Desenvolvimento de Tecnologias Computacionais } \\
\text { de Apoio à Aprendizagem ao Longo da Vida. In: XXXVII Congresso da Sociedade Brasileira de } \\
\text { Computação, } 6^{\circ} \text { Desafie. São Paulo, Brasil, } 2017 \text {. }\end{array}$ \\
\hline Towards LDF4MOOCs & $\begin{array}{l}\text { Fassbinder, A. G. O.; Fassbinder, M., Barbosa, E. F., and Magoulas, G. (2016) Towards a MOOC } \\
\text { Design Model based on Flipped Learning and Patterns: A Case on Introductory Courses. In: } \\
\text { XXI Congresso Internacional de Tecnologia Educativa (TISE), Santiago, Chile, } 2016 .\end{array}$ \\
\hline $\begin{array}{l}\text { Pedagogical } \\
\text { requirements for MOOC } \\
\text { Platforms }\end{array}$ & $\begin{array}{l}\text { Fassbinder, A. G. O.; Fassbinder, M. and Barbosa, E. F. (2016) Um Conjunto Preliminar de } \\
\text { Requisitos Pedagógicos para Caracterização e Comparação de Plataformas de MOOCs. In: XXI } \\
\text { Congresso Internacional de Tecnologia Educativa (TISE), Santiago, Chile, } 2016 .\end{array}$ \\
\hline $\begin{array}{l}\text { Flipped Learning as a } \\
\text { pedagogical strategy for } \\
\text { the LDF4MOOCs }\end{array}$ & $\begin{array}{l}\text { Fassbinder, A. G. O.; Fassbinder, M. and Barbosa, E. F. (2015) From flipped classroom theory to } \\
\text { the personalized design of learning experiences in MOOCs. In: } 45^{\text {th }} \text { IEEE Frontiers in Education } \\
\text { (FIE) Conference. El Paso, USA, } 2015 \text {. }\end{array}$ \\
\hline $\begin{array}{l}\text { Systematic Review on } \\
\text { MOOCs }\end{array}$ & $\begin{array}{l}\text { Fassbinder, A. G. O.; Delamaro, M. E. and Barbosa, E. F. (2014) Construção e Uso de MOOCs: } \\
\text { Uma Revisão Sistemática. In: XXV Simpósio Brasileiro de Informática na Educação (SBIE), } \\
\text { Dourados, MS, Brasil, 2014. }\end{array}$ \\
\hline $\begin{array}{l}\text { Flipped Learning in a } \\
\text { face-to-face course }\end{array}$ & $\begin{array}{l}\text { Fassbinder, A. G. O. et al. (2014) Applying flipped classroom and problem-based learning in a } \\
\text { CS1 course. In: } 44^{\text {th }} \text { IEEE Frontiers in Education (FIE) Conference. Madrid, Spain, } 2014 .\end{array}$ \\
\hline $\begin{array}{l}\text { Flipped Learning in a } \\
\text { face-to-face course }\end{array}$ & $\begin{array}{l}\text { Fassbinder, A. G. O. et al. (2014) Tools for the flipped classroom model: An experiment in teacher } \\
\text { education. In: } 44^{\text {th }} \text { IEEE Frontiers in Education (FIE) Conference. Madrid, Spain, } 2014 .\end{array}$ \\
\hline
\end{tabular}

Future works include: (i) more experiments to validate the LDF4MOOCs framework; (ii) the Educational Design Pattern Language can be extended to support additional aspects related to the development of Open Educational Resources as well as new kinds of active learning strategies and assessments; (iii) in an resulting study, we identified an initial set of pedagogical requirements that can be used to define, analyze, improve and compare MOOCs platforms [Fassbinder, Fassbinder and Barbosa 2016]. Thus, future research must focus on how better use knowledge from MOOC design research to improve the development of platforms and providers.

\section{Acknowledgments}

Institute of Education, Science and Technology of South of Minas Gerais and the Brazilian Funding Agencies CAPES, CNPq, and FAPESP. Thanks to George Magoulas and the Birkbeck College - University of London for having me during my internship in the London Knowledge Lab. 
VIII Congresso Brasileiro de Informática na Educação (CBIE 2019)

Anais dos Workshops do VIII Congresso Brasileiro de Informática na Educação (WCBIE 2019)

\section{References}

Alario-Hoyos, C. et al. (2014) "Proposal for a Conceptual Framework for Educators to Describe and Design MOOCs", Journal of Universal Computer Science, v. 20, n. 1, p. 6-23.

Alexander, C., Ishikawa, S. and Silverstein, M. (1977) “A Pattern Language: towns, building, construction”, [s.l: s.n.].

Anderson, T. and Shattuck, J. (2012) "Design-Based Research: A Decade of Progress in Education Research?”, Educational Researcher, v. 41, n. 1, p. 16-25.

Bannan, B. (2013) "The Integrative Learning Design Framework: An Illustrated Example from the Domain of Instructional Technology", In: NIEVEEN, T. P. \& N. (Ed.). Educational Design Research. Enschede, p. 114-133.

Bergmann, J., Sams, A. (2014) "Flip Your Classroom Reach Every Student in Every Class Every Day".

Braga, R. T. V., Ré, R. and Masiero, P. C. (2007) "A Process to Create Analysis Pattern Languages for Specific Domains", Proceedings of SugarLoafPLoP.

Branch, R. M. (2010) "Instructional design: The ADDIE approach", [s.l: s.n.].

Brouns, F. et. Al. (2014) “A networked learning framework for effective MOOC design: the ECO project approach", Challenges for Research into Open \& Distance Learning. Oxford, United Kingdom., p. 161-171.

Conole, G. (2014) “A New Classification Schema for MOOCs”, The International Journal for Innovation and Quality in Learning, n. 3, p. 65-77.

Dalziel, J. et al. (2016) "The Larnaca Declaration on Learning Design”, Journal of Interactive Media in Education.

Fassbinder, A. G. O., Delamaro, M. E. and Barbosa, E. F. (2014) "Construção e Uso de MOOCs: Uma Revisão Sistemática", Brazilian Symposium on Computers in Education (SBIE 2014).

Fassbinder, A. G. O., Fassbinder, M., Barbosa, E. F. and Magoulas, G. (2016) "Towards a MOOC Design Model based on Flipped Learning and Patterns: A Case on Introductory Courses", In: XXI Conferência Internacional sobre Informática na Educação (TISE). Santiago, Chile.

Fassbinder, A. G. O., Barbosa, E. F. and Magoulas, G. D. (2017a) "Developing an Educational Design Pattern Language for MOOCs", Brazilian Symposium on Computers in Education (SBIE 2017).

Fassbinder, A. G. O., Barbosa, E. F. and Magoulas, G. D. (2017b) “Towards an Educational Design Pattern Language for Massive Open Online Courses", 24th Conference on Pattern Languages of Programs (PLoP). Vancouver.

Fassbinder, A. G. O. et al. (2017c) "Massive open online courses in software engineering education", IEEE Frontiers in Education Conference (FIE). Indianapolis.

Fassbinder, A. G. O. (2018) "A contribution to the process of designing for learning in Massive Open Online Courses (MOOCs)”, Ph.D. thesis, Universidade de São Paulo (PPG-CCMC).

Hew, K. F. and Cheung, W. S. (2014) 'Students' and instructors' use of massive open online courses (MOOCs): Motivations and challenges", Educational Research Review.

Iba, T., Sakamoto, M. and Miyake, T. (2011) "How to Write Tacit Knowledge as a Pattern Language: Media Design for Spontaneous and Collaborative Communities", Procedia: Social and Behavioral Sciences, v. 26, p. 46-54.

Koper, R. and Tattersall, C. (2005) “Learning Design: A Handbook on Modelling and Delivering Networked Education and Training", Journal of Interactive Media in Education.

Lee, G. et al. (2016) “A study on the development of a MOOC design model”, Educational Technology International.

Liyanagunawardena, T. R., Kennedy, E. and Cuffe, P. (2015) "Design patterns for promoting peer interaction in discussion forums in MOOCs", Open Education Europa. eLearning Papers, n. 42.

Margaryan, A., Bianco, M. and LittleJohn, A. (2015) "Instructional quality of Massive Open Online Courses (MOOCs)", Computers and Education, v. 80, p. 77-83.

Mcauley, A. et al. (2010) “The MOOC model for digital practice”, Massive Open Online Courses: digital ways.

Mckenney, S. E. and Reeves, T. C. (2012) "Conducting educational design research", Recherche, p. 256.

Meszaros, G. and Doble, J. (1997) “MetaPatterns: A Pattern Language for Pattern Writing”, PLoP 97.

Pressman, R. S. (2009) “Software Engineering A Practitioner’s Approach”, 7th Ed - Roger S. Pressman. [s.l: s.n.].

Sergis, S., Sampson, D. G. and Pelliccione, L. (2016) "Educational design for MOOCs: Design considerations for technology-supported learning at large scale", In: Lecture Notes in Educational Technology. [s.l: s.n.]. p. 39-71.

Schophuizen, M. et al. (2018) "Eliciting the challenges and opportunities organizations face when delivering open online education: A group-concept mapping study", Internet and Higher Education, v. 36.

Silva, V. M., Barbosa, E. F. and Fassbinder, A. (2017) "Ferramenta Web de Apoio à Validação de Mapas de Aprendizagem para MOOCs", Anais do APPs.Edu, Congresso Brasileiro de Informática na Educação.

Warburton, S. and Mor, Y. (2015) “A set of patterns for the structured design of MOOCs", Open Learning: The Journal of Open, Distance and e-Learning, v. 30, n. 3, p. 206-220.

Zhu, M., Sari, A. and Lee, M. M. (2018) "A systematic review of research methods and topics of the empirical MOOC literature (2014-2016)", Internet and Higher Education, v. 37, p. 31-39. 